\title{
Marine environment monitoring in coastal Sicilian waters
}

\author{
G. Zappalà, G. Caruso, F. Azzaro \& E. Crisafi \\ Istituto per l'Ambiente Marino Costiero, Consiglio Nazionale Ricerche, \\ Messina, Italy
}

\begin{abstract}
Marine Coastal Monitoring is a basic instrument for the assessment of environmental quality and detection of pollution phenomena. This paper describes the evolution of instruments and techniques in the last 20 years, together with some results from national and EU funded research programmes. Keywords: pollution, monitoring, coastal areas, Escherichia coli, buoys.
\end{abstract}

\section{Introduction}

Due to their position at the interface between land and the sea, coastal areas represent very important sites for the global equilibrium of marine ecosystems; in these areas, multiple interests converge, linked to the tourism, recreational or productive activities.

In recent years increasing importance has been addressed to the protection and preservation of the marine environment, in particular of those coastal areas, which suffered greater impact from anthropogenic activities; this has in turn stimulated the start of research programs devoted to the monitoring and surveillance of these particular zones, coupling the needs for their use, and the sustainable development and exploitation of natural resources.

The management and safeguard of coastal ecosystems rely on continuous monitoring of environmental parameters.

Traditional oceanographic techniques, based on ship surveys, hardly fit the needs of coastal water monitoring, because of their high cost and fragmentary nature, both in spatial and temporal domains. To obtain a good sinopticity, it is necessary to complement ship observations with measurements from fixed stations (buoys moored in sites chosen to be representative of wider areas, or to 
constitute a sentinel against the arrival of pollutants), satellite observations and use of newly developed devices, like the gliders.

The set up of the system of marine monitoring and oceanographic forecasting, completed with an observation network, a data collection and communication network, represents the fundamental basis on which a forecast-alarm and service network and a data quality control system relies, as described, among others, by Carof et al. [1], Grisard [2], Eriksen [3], Griffiths et al. [4], Irish et al. [5], Paul [6], Seim et al. [7], Zappalà et al. [8], Nittis et al. [9] and Pinardi et al. [10].

\section{Advanced monitoring systems}

In 1988 the Italian National Research Council launched the strategical Project "Automatic Monitoring of Marine Pollution in Southern Italian Seas". To the project, coordinated by the Istituto Talassografico of Messina (now CNRIAMC), participated several research units, each focusing on a specific problematic (biological, chemical, laboratory methods, in situ methods, instrument development...).

The most important activity set up a monitoring system in Augusta Bay, an important site near Siracusa, where oil refineries and industrial plants coexist with an important commercial and military harbour [11].

Five small buoys were moored to measure water temperature, salinity, dissolved oxygen, fluorescence and turbidity (Figure $1 \mathrm{left}$ ); periodical surveys were performed with a small boat, in coincidence with the passage of Landsat satellite on the bay to obtain the calibration of the image parameters to the real measures and satellite images elaborated.

The data transmission from the buoys to the local control computer in Augusta used an UHF link, the data were locally stored and transferred once a day to Messina using a standard phone line.

The measures were autonomously managed by the local control computer that "woke up" the buoys and asked for measurements at 1-hour intervals.

The data acquisition and transmission system of the buoys was based on a 8088 PC normally off. The presence of a radio signal switched on the data acquisition subsystem, a timer switched it off again after some minutes of absence of radio communication to spare the batteries that were to be substituted (to be recharged) every 10-15 days because the size of the buoy didn't allow to install solar panels. The buoys recognised following commands: Identification, Measure and Transmission, Switch Off.

In the northern part of the Bay, having low depth and low water flows, high chlorophyll 'a' values were usually measured. This complied with the bibliographic data locating in that area the source of the wide phytoplanktonic blooms happened in the past. On the west coast, and especially in the southern part, flows coming from the industrial plants were observed; the zone always showed the highest temperature values, so confirming the presence of exhausted cooling waters (Figure 1 right). 

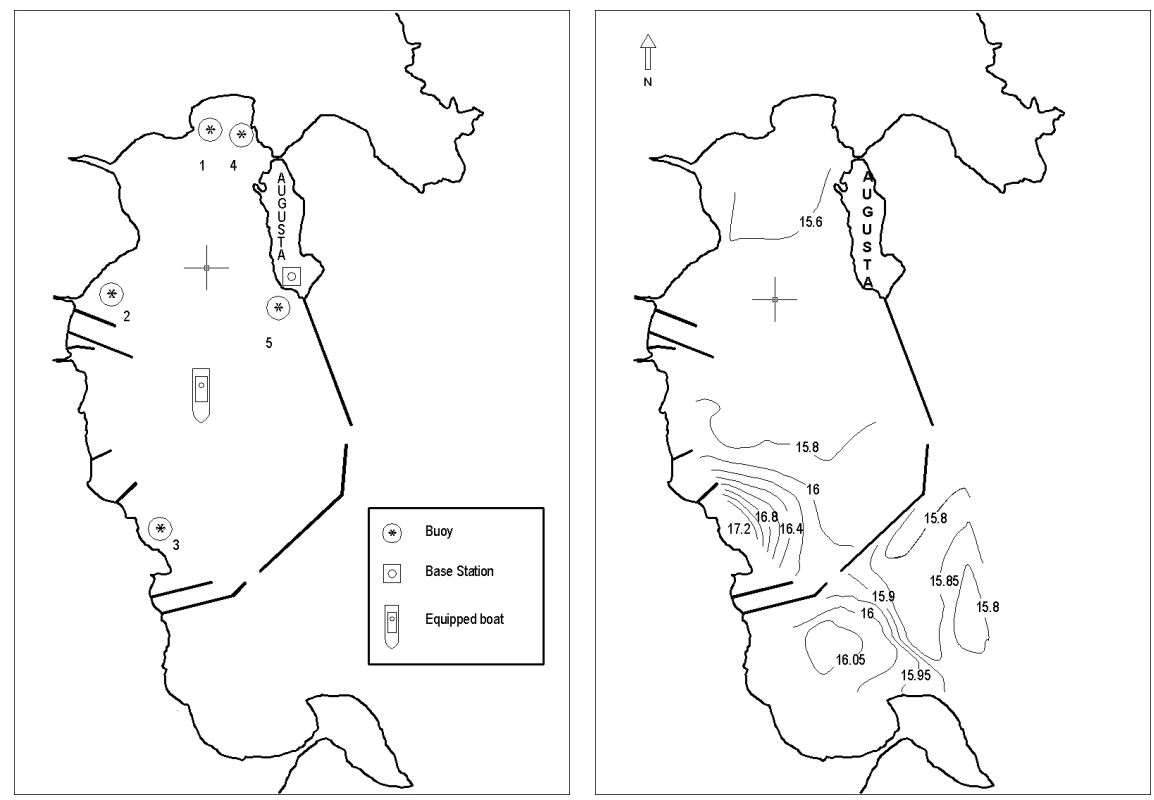

Figure 1: Augusta Bay with the buoys and the base station (left) and isothermal curves showing the influence of a thermal effluent (right).

The programme lasted up to 1994, then for some years no new experiments were performed in Sicily, but technological development went on with the participation of the Institute to some nationally funded programs.

In the first of these programs "Sistema Lagunare Veneziano" (Venice Lagoon System), a new electronic data acquisition and transmission system was designed, still using an UHF link, together with a packet switching modem. Based on an industrial PC 286 computer, this device was the first-born of the new generation. The same architecture, implemented on newer 486 boards was experimented later also in Messina Straits, mounted on a platform obtained modifying and linking together the bodies of four of the buoys formerly used in Augusta Bay. This new platform, equipped with solar panels to recharge batteries, Meteo Station, CTDO probe, Automatic Water Sampler for Bacteriological Analysis, $\mu$ Mac Colorimetric Analyzers for Ortho-Phosphate and Ammonia was moored in 1996 on a 20 meter depth near an urban sewer, in an area called "Maregrosso" in which periodic (6 hours) tidal streams produce a continuous mixing of sea and waste waters [12]. The buoy was moored in such a position that it was in a zone always affected from the waste (as can be seen from the low salinity showed in figure 2), but feeling also the effect of the tidal streams: with "montante" (South to North stream) the buoy felt the effect of upwelling Ionian waters (cold and clean), taking the waste waters away from the platform (and hence lower temperature and nutrient levels), while during "scendente" (North to South stream) the warm Tyrrhenian surface waters 
brought the waste waters closer to the platform (and hence higher temperature and nutrient levels).

Trends of temperature and salinity are reported for a standard week in Figure 2; noticeable are the minimum temperature peaks (around the midnight), strictly related with the positive salinity peaks; this kind of behaviour is indicative of the arrival of intermediate Ionian water, colder and richer of nutrients.
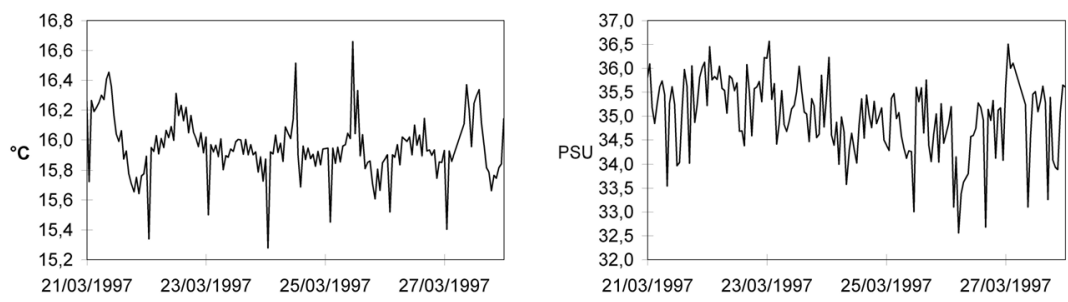

Figure 2: $\quad$ Water temperature (left) and salinity (right) in Maregrosso.

Daily Ortho-phosphates and Ammonia trends are reported in Figure 3; among the two nutrients examined, Ortho-phosphate felt more the effect of the proximity of the urban sewer because detergents distribute in the surface layer, in proximity of the water-air interface, while dissolved ammonia concentration felt the effect of dilution of the stream. The Ortho-phosphate values evidenced a trend similar to the temperature one, so indicating the arrival of less diluted sewage near the buoy. It is interesting the peak in ammonia at 9 a.m., just in the middle of the "scendente" phase, and not at its top: it is surely due to the varying ammonia flux in the sewer strictly related to the higher anthropic load in the early morning.
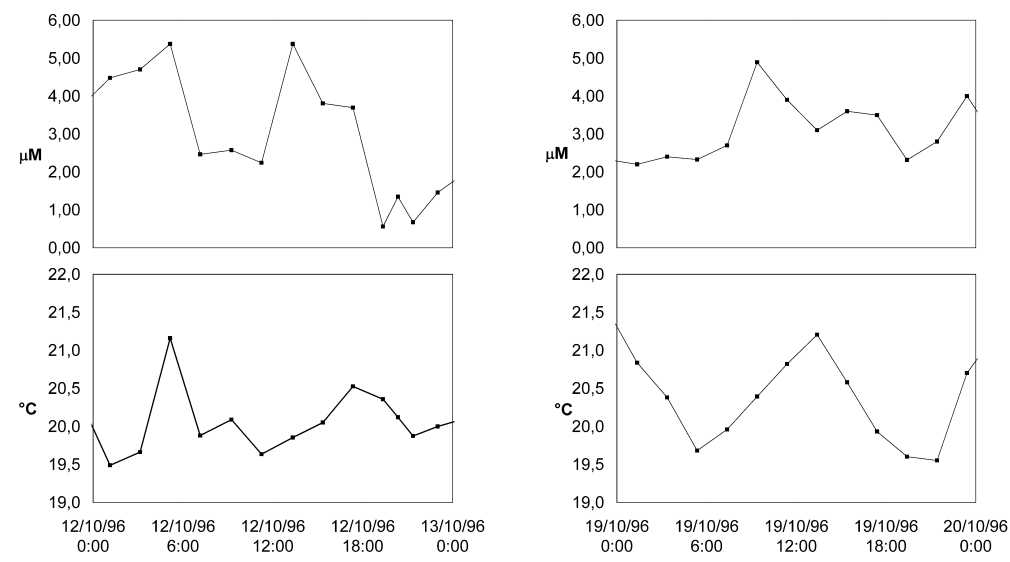

Figure 3: Ortho-phosphate (left) and Ammonia (right) compared to water temperature measured by Maregrosso buoy. 
In the meantime, as a part of the "PRISMA 2" program, a new electronic was designed; based on PC104 boards, it incorporated a cellular phone for data transmission, so making unnecessary the expensive and intrusive UHF radio link to the base station [13]. This new device offered at an affordable cost a good value that further increased when connection providers started to offer new services like SMS, e-mail from SMS, and GPRS Internet access.

A great technological improvement was obtained in the framework of the SAM (Advanced Monitoring Systems) program, in which a network of seven coastal buoys (moored in Messina, Milazzo, Palermo, Siracusa, Mazara del Vallo, Taranto and Lesina) and one 15 metres monitoring boat was set up, as described by Zappalà et al. [14, 15]. The buoys were equipped with a new, powerful computer system, described by Zappalà [16].

The most important buoy, moored in Messina Straits, was the one formerly in Maregrosso, completely refurbished with new instruments and an enhanced buoyancy; the basic equipment included in situ temperature sensors at five depths, a system pumping water from the same depths into a measurement chamber where a CTDO probe with fluorometer and turbidimeter was fitted, a colorimetric Nutrient Probe Analyzer (NPA), a Meteo station; Messina platform also hosted a new bacteriological water sampler, described in Zappalà et al. [17]. In situ temperatures measured from Milazzo (Figure $4-1$ eft) and Messina (Figure 4 - right) platforms show the different hydrological conditions of the two sites. Water stratification is evident in Milazzo: minimum values are measured by the 25-meter sensor (the deepest) and the maximum ones by the 5-meter sensor (the shallowest). Nychthemeral variations can be observed, with thermal increments during the central hours of the day. A mixing of the water column can instead be observed in Messina: temperature variations observed are caused by the tidal alternance of "montante" and "scendente" streams, with little variations among the different depths.
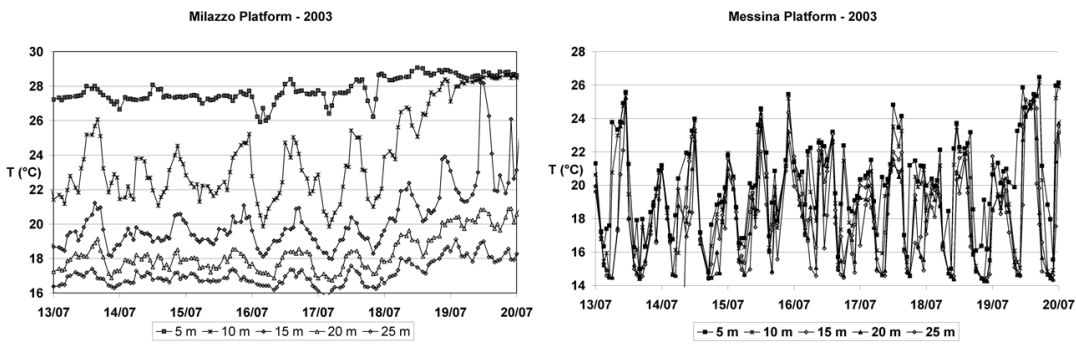

Figure 4: Temperatures measured from Milazzo (Left) and Messina (Right) platforms.

The monitoring boat was equipped with a set of new Systea $\mu$ Mac fast colorimetric analyzers, providing measures of $\mathrm{NO}_{3,2}, \mathrm{NH}_{4}, \mathrm{PO}_{4}$ every 300 seconds, described by Azzaro and Galletta [18]. Some results of coastal cruises performed in the Gulf of Milazzo are showed in Figure 5. The highest concentrations of nitrates (from 5 to $11 \mu \mathrm{M}$ ) were evident in March going 
eastwards, due to the effects of the Niceto River outflow and in presence of the most oligohaline waters; in July, in the westernmost area, due to the effects of tourism increase, inputs with values above $2 \mu \mathrm{M}$ and variations could not be correlated with salinity. In November concentrations varied in a rather low range with sporadic peaks along the track. Ammonium nitrogen concentrations decreased in average from 2 to $0.7 \mu \mathrm{M}$ near the southern coast, through the increasing salinity from spring to autumn, whilst orthophosphate concentration were generally increased from under the threshold of $0.5 \mu \mathrm{M}$ until November, when the maximum value of $0.7 \mu \mathrm{M}$ was found.
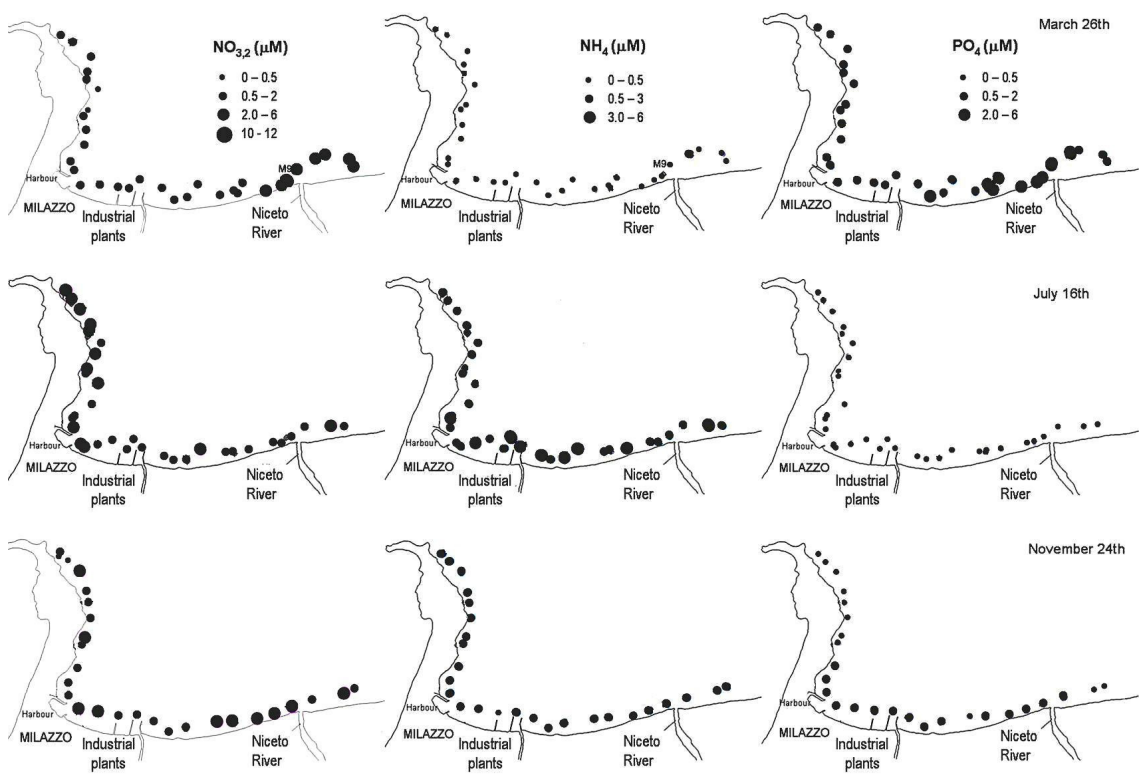

Figure 5: $\quad$ Nutrients measured in Milazzo Gulf in 2003.

\section{Advanced laboratory protocols}

As a part of the advancement in the tools specific for marine environment monitoring, new analytical protocols were developed for the detection and enumeration of faecal contamination indicators, such as Escherichia coli. The search for this microorganism, together with enterococci, is prescribed by the recent Proposal of the Directive of the European Parliament and Council for the quality of bathing waters (COM (2002) 581), approved by the European Council (June, 28, 2004). The protocols were set up by the Laboratory of Microbiology of our Institute through preliminary trials performed on seawater samples experimentally inoculated with the $E$. coli 0125 reference strain (enteropathogenic serotype); further optimisation, they were applied to 
environmental samples collected from coastal areas showing a wide range of faecal contamination.

Since 1989, the following Sicilian areas were screened for the occurrence of faecal contamination: the Augusta Gulf, the Straits of Messina, the Gulf of Palermo, the Milazzo Gulf. At the first time, such as in Augusta Gulf, the detection of faecal indicators relied on the specificity of the antigen-antibody reaction through the use of immune antisera specific for $E$. coli enteropathogenic serotypes; a comparison of the results obtained by these two methods during the Strategical Project CNR “Automatic Monitoring of Marine Pollution in Southern Italian Seas" is reported in Figure 6. Plate (FC) counts were more spatially variable with respect to the microscopic (FA) ones, which showed the homogeneous presence of E.coli at the stations examined. Since 1996, besides the FA method, further experimentation was performed using as a target molecule the enzyme $\beta$-glucuronidase, specific for E. coli and Shigella, whose the potential activity rate was detected in a biochemical assay (MUG) carried out with the fluorogenic substrate 4-methylumbelliferyl- $\beta$-D-glucuronide. The experimental procedures developed, particularly in the framework of the SAM Project funded by Italian Ministry of Scientific Research (MIUR), were described in detail in previous studies $[14,19,20]$.

Figures 7-8 report some examples of the measurements obtained from coastal samples collected from Messina Straits by comparing the two (microscopic and enzymatic) methods, together with their Pearson correlation coefficients with the standard plate counts. Both methods proved to be enough sensitive and specific to be successfully applied for early warning of faecal contamination.

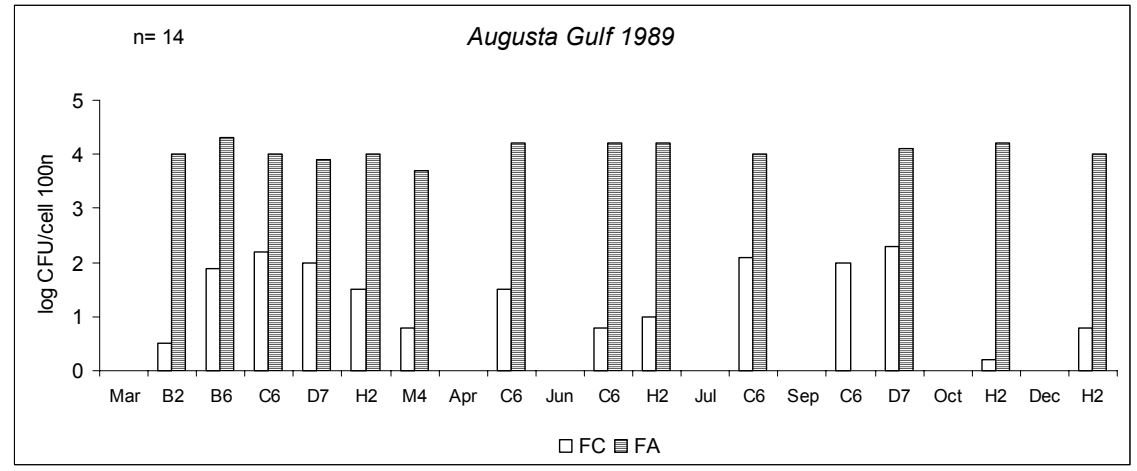

Figure 6: Escherichia coli concentration found in 1989 in Augusta Gulf, as detected by plate (FC) and microscopic (FA) methods.

In Messina Straits, in spite of some quantitative differences due to the different principle of FC and FA methods (culturability and antigenic profiles, respectively), the distribution of FA counts reflected that recorded by plate counts, as also suggested by the significant correlation coefficients computed. The course of MUG activity values was also similar to the trend followed by the abundance data, although correlation coefficients with FC values were lower 
than those found between FC and FA. Both abundance and activity data revealed a worsening in the levels of bacteriological quality of seawater from 1996 to 2004.

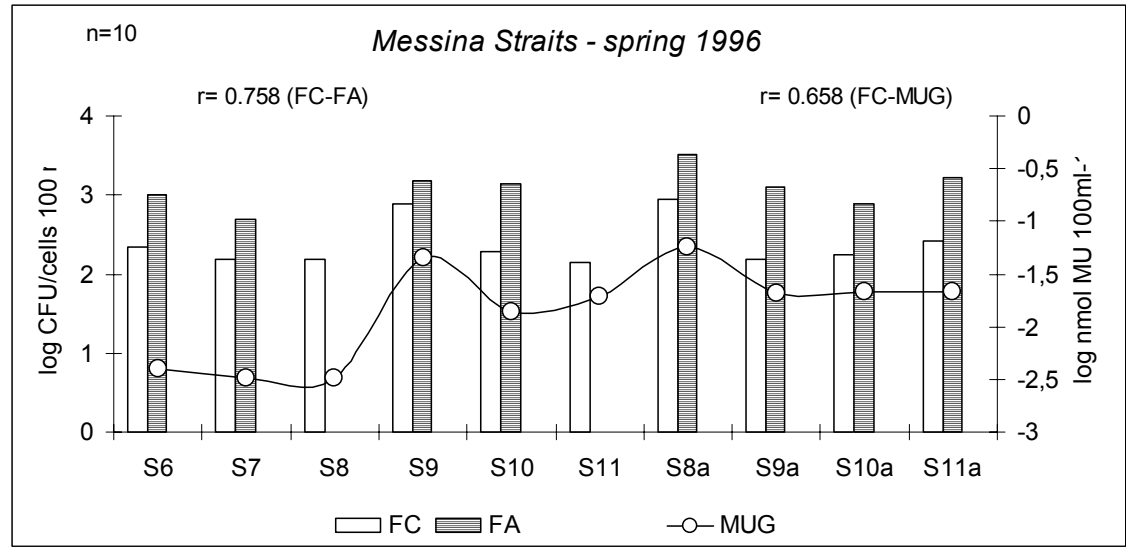

Figure 7: Escherichia coli concentration found in 1996 at some coastal stations along the Messina Straits, as detected by plate (FC) and microscopic (FA) methods (y-axis); $\beta$-glucuronidase activity (MUG) rates are also reported (secondary y-axis).

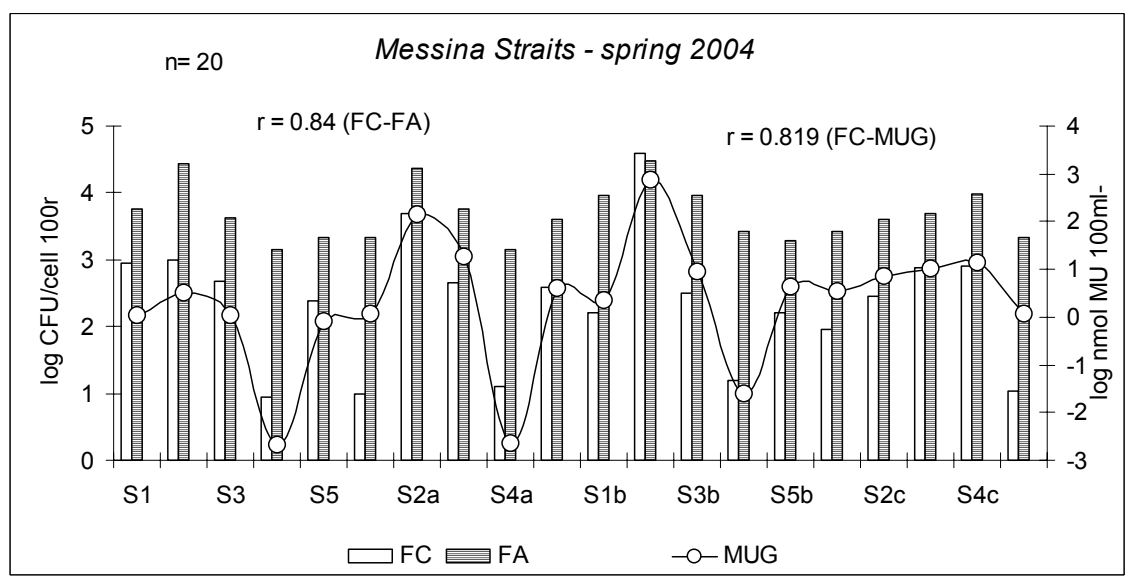

Figure 8: Escherichia coli concentration found in 2004 at some coastal stations along the Messina Straits, as detected by plate (FC) and microscopic (FA) methods (y-axis); $\beta$-glucuronidase activity (MUG) rates are also reported (secondary y-axis).

In the area, many point sources of faecal contamination, largely exceeding the values prescribed by Italian directive (DPR 470/82) for bathing waters (FC: 100 CFU/100ml), were observed. 


\section{Conclusions}

The above reported cases describe only a few examples of coastal marine monitoring performed through the application of new instruments and techniques. Advancement in this field of research is still in progress and offer interesting perspectives for future development. A multidisciplinary and integrated approach of study, combining together physical, chemical and biological measurements of selected environmental indicators, is considered the goal to assess the quality status of coastal areas and preserve their integrity.

\section{References}

[1] Carof, A., H., Sauzade D. \& Henocque, Y., Arcbleu, an integrated surveillance system for chronic and accidental pollution. Proc. of OESIEEE OCEANS '94 Conference, III, pp. 298-302, 1994.

[2] Grisard, K., Eight years experience with the Elbe Estuary environmental survey net. Proc. of OES-IEEE OCEANS '94 Conference, I, pp. 38-43, 1994.

[3] Eriksen, C. C., Instrumentation for Physical Oceanography: the last two decades and beyond. NSF APROPOS Workshop - Ailomar, CA 15-17 December 1997.

[4] Griffiths, G., Davis, R., Eriksen, C., Frye, D., Marchand, P. \& Dickey, T., Towards new platform technology for sustained observations. Proc. of OceanObs 99, http://www.bom.gov.au/OceanObs99/Papers/Griffiths.pdf

[5] Irish, J. D., Beardsley, R. C., Williams, W. J. \& Brink, K. H., Long-term moored observations on Georges Bank as part of the U. S. Globec Northwest Atlantic/Georges Bank program. Proc. of MTS-IEEE OCEANS '99 Conference, I, pp. 273-278, 1999.

[6] Paul, W., Buoy Technology. Marine Technology Society Journal, 35(2), pp. 54-57, 2001.

[7] Seim, H., Werner, F., Nelson, J., Jahnke, R., Mooers, C., Shay, L., Weisberg, R. \& Luther, M., SEA-COOS: Southeast Atlantic Coastal Ocean Observing System. Proc. of MTS-IEEE OCEANS 2002 Conference, I, pp. 547-555, 2002.

[8] Zappalà, G., Caruso, G. \& Crisafi, E., Design and use of advanced technology devices for sea water monitoring. Operational Oceanography. Implementation at the European and regional Scales, eds. N.C. Flemming, S. Vallerga, N. Pinardi, H.W.A. Behrens, G. Manzella, D. Prandle \& J.H. Stel, Elsevier Oceanography Series, 66, 2002.

[9] Nittis, K., Tziavos, C., Thanos, I., Drakopoulos, P., Cardin, V., Gacic, M., Petihakis, G. \& Basana, R., The Mediterranean Moored Multi-sensor Array (M3A): system development and initial results. Annales Geophysicae, 21, pp. 75-87, 2003.

[10] Pinardi, N., Allen, I., Demirov, E., De Mey, P., Korres, G., Laskaratos, A., Le Traon, P., Y., Maillard, C., Manzella, G. \& Tziavos, C., The 
Mediterranean Ocean Forecasting System: first phase of implementation (1998-2001). Annales Geophysicae, 21, pp. 3-20, 2003.

[11] Crisafi, E., Azzaro, F., Zappalà, G. \& Magazzù G., Integrated automatic systems for oceanographic research: some applications. Proc. of OESIEEE OCEANS '94 Conference, I, pp. 455-460, 1994.

[12] Zappalà, G., Crisafi, E., Caruso, G., Azzaro, F. \& Magazzù, G., Coastal monitoring by an advanced technology platform. Proc. of Oceanology International 98 Conference, I, pp. 69-84, 1998.

[13] Zappalà, G., Alberotanza, L., Crisafi, E., Automatic monitoring on an unmanned offshore platform. Proc. of The Marine Technology Society Annual Conference - Ocean Community Conference '98 - Celebrating 1998 International Year of the Ocean, I, pp. 585-589, 1998.

[14] Zappalà, G., Caruso, G. \& Crisafi, E. The "SAM" integrated system for coastal monitoring. Proc. Of the $4^{\text {th }}$ Int. Conf. On Environmental Problems in Coastal Regions, Coastal Environment IV, ed C.A. Brebbia, WIT Press: Southampton, pp. 341-350, 2002.

[15] Zappalà, G., Caruso, G., Azzaro, F., Crisafi, E., Integrated Environment Monitoring from Coastal Platforms. Proc. of the Sixth International Conference on the Mediterranean Coastal Environment, ed E. Ozhan, MEDCOAST, Middle East Technical University: Ankara, 3: pp. 20072018, 2003.

[16] Zappalà, G., A software set for environment monitoring networks. Proc of the Tenth International Conference on Development and Application of Computer Techniques to Environmental Studies, Envirosoft 2004, eds G. Latini, G. Passerini, \& C.A. Brebbia, WIT Press: Southampton, pp. 3-12, 2004.

[17] Zappalà, G., Caruso, G., Crisafi E., Coastal pollution monitoring by an automatic multisampler coupled with a fluorescent antibody assay. Proc. Of the $5^{\text {th }}$ Int. Conf. On Environmental Problems in Coastal Regions, Coastal Environment V, eds C.A. Brebbia, J.M. Saval Perez, L. Garcia Andion \& Y. Villacampa, WIT Press: Southampton, pp. 125-133, 2004.

[18] Azzaro, F., Galletta, M., Automatic colorimetric analyzer prototype for high frequency measurement of nutrients in seawater. Marine Chemistry, 99, pp. 91-198, 2006.

[19] Caruso, G., Zaccone, R. \& Crisafi, E., Use of the indirect immunofluorescence technique for detection and enumeration of Escherichia coli in seawater samples. Letters Applied Microbiology, 31(4), pp. 274-278, 2000.

[20] Caruso, G., Denaro, R., Genovese, M., Giuliano, L., Mancuso, M. \& Yakimov, M.M., New methodological strategies for detecting bacterial indicators. Chemistry and Ecology, 20(3), pp. 167-181, 2004. 